\title{
与薬における過剩投与・過小投与の原因薬と発生要因
}

\author{
鈴木亮平 ${ }^{* 1,2}$, 深津 哲 $^{1}$, 大津史子 $^{2}$ \\ 独立行政法人国立病院機構東名古屋病院薬剂部 ${ }^{* 1}$, 名城大学薬学部医薬品情報学研究室 ${ }^{2}$
}

\section{Analysis of Contributing Factors and Related Drugs in Incidents of Excessive Dosing or Underdosing}

\author{
Ryohei Suzuki ${ }^{* 1,2}$, Satoshi Fukatsu ${ }^{1}$ and Fumiko Ohtsu ${ }^{2}$ \\ Department of Pharmacy, National Hospital Organization Higashinagoya National Hospital*1, \\ Drug Informatics, Faculty of Pharmacy, Meijo University ${ }^{2}$ \\ $\left[\begin{array}{l}\text { Received January 1, } 2018 \\ \text { Accepted April 23, } 2018\end{array}\right]$
}

The most frequently reported medical incidents were drug-related and made by nurses.

Excessive dosing can cause adverse reactions and possibly lead to patient deaths. On the other hand, underdosing can delay treatment and prolong hospitalization. We investigated drugs associated with and factors leading to excessive dosing or underdosing incidents to clarify when pharmacists should intervene to reduce medication-related incidents. We analyzed incident reports collected by the Japan Council for Quality Health Care between January 2009 and June 2015. In total, we found 3,024 cases of excessive dosing and 2,119 cases of underdosing. In the excessive dosing group, dosing errors and the administration of an excessive dose without an order to do so comprised 785 cases and 482 cases, respectively. In the underdosing group, there were 902 cases of dosing errors and 366 cases where the dose was discontinued too early.

We used logistic-regression analysis to compare cases of causative drugs and incident factors with dosing errors and other medical incidents. Our analysis revealed that there was a significant association between steroids, narcotic analgesics, antibacterial drugs and both excessive dosing and underdosing incidents. Also, there was a significant association between nurses not confirming the correct dose and misdosing incidents.

It is easy for dosing errors to occur with the aforementioned drugs because the correct dosage varies with the patient's age, renal function, overall condition, and test results. These findings suggest that pharmacists in hospital wards need to check the correct dosage before administering the medication to prevent dosing errors.

Key words — medical incident, excessive dosing, underdosing, pharmacist, safety

\section{緒 言}

公益社団法人日本医療機能評価機構が実施した 平成 27 年度の医療事故情報収集等事業年報のヒ ヤリ・ハット報告では薬剤に関連する事例が 1 番 多く，1 年間で約 26 万件報告されている．また， 発生場面では与薬に関する場面が 1 番多く, 当事 者職種では看護師が最も多く報告されている (http://www.med-safe.jp/pdf/year_report_2015.pdf,
2017 年 4 月 22 日). 与薬のなかでも薬剤の過剩 投与は薬の効果を強め副作用の原因となり, 死亡 事例も報告されている（薬の過剰投与で 69 歳女 性が死亡, 日本経済新聞, 2017 年 9 月 29 日).一方, 過小投与は患者の治療を遅らせ, 病態悪化や入院 期間が延長する原因となり対策が急務である.

これまでに, 看護師の勤務形態・経験年数などの 要因分析に基づいた医療過誤防止対策は行われて いる. ${ }^{1,2}$ 薬剤面からの分析および防止対策は，イン

\footnotetext{
* 个468-8620 愛知県名古屋市名東区梅森坂5-101
} 
スリンの投与量間違いや，カリウム製剤の急速静注 に焦点を当てて行われているが（http://www.medsafe.jp/pdf/report_2010_4_R002.pdf, 2018年 2 月 4 日) ( http://www.med-safe.jp/pdf/report_2014_4_T002.pdf, 2018 年 2 月 4 日), ほかの薬剤では行われていない.

2012 年 4 月の診療報酬改定で, 医療安全の推 進や医療の質の向上等を目的として病棟薬剤業務 実施加算が新設された，薬誵師の病棟に㧍ける業 務を通して, 病棟に抢ける薬郕に関するインシデ ント・アクシデントの減少に薬剤師が貢献するこ とが期待されている（http://www.jshp.or.jp/cont/ 16/0609-2.pdf, 2017 年 4 月 22 日). しかし, 具体 的な方法は示されていない.

今後，薬片師が過剩投与 - 過小投与のヒヤリ ・ ハット減少につなげる業務改善を行うためには, ヒヤリ・ハットが最も多い与薬場面の現状を把握 し，対策を講じることが必要である，そこで，ヒ ヤリ・ハットが最も多く，与薬の際に当事者とな りやすい看護師に扔ける, 原因薬や発生要因の現 状を分析し，薬剤師の介入すべき点を明確にする ことを目的に調查を行った。

\section{方 法}

\section{1. 調査対象}

調査対象は公益社団法人日本医療機能評価機構 が医療事故情報収集等事業のホームページ （http://www.med-safe.jp/, 2015 年 12 月 5 日）で公 開している 2009 年 1 月 1 日〜2015 年 6 月 30 日 のヒヤリ・ハット事例とした。

公益社団法人日本医療機能評価機構は国民の健 康と福祉の向上に寄与することを目的として，医 療の質の向上と信頼できる医療の確保に関する事 業を行っている，その一環として医療安全対策の 一層の推進を図るため, 薬郕や輸血, 医療機器, 療養上の世話などで起きたヒヤリ・ハット事例の 収集を行っている。これらの事例は国立高度専門 医療研究センターおよび国立ハンセン病療養所, 独立行政法人国立病院機構の開設する病院, 大学 病院, 特定機能病院など全国の医療機関から収集 されている。また，ヒヤリ・ハット事例には発生 年.月や当事者職種, 職種経験年数, 関連医薬品,
事例の内容, 発生要因, 事例概要などの情報が収 録されている.

今回, 薬荗に関するヒヤリ・ハット事例のうち, 事例の内容で「過小投与」と「過小投与準備（与 薬の準備段階で発見された過小投与にかかわるヒ ヤリ・ハット)」を合わせた過小投与群,「過剩投 与」と「過剩投与準備 (与薬の準備段階で発見さ れた過剩投与にかかわるヒヤリ・ハット)」を合 わせた過剩投与群を対象として検討を行った.

\section{2. 調査項目}

調查項目はヒヤリ・ハット内容と当事者経験年 数, 原因薬, 発生要因とした.

事例内には実際にどのような過剩投与, 過小投 与のヒヤリ・ハットが起きたかを分類する項目が ないため, ヒヤリ・ハット内容を分類した。 ヒヤ リ・ハット内容の分類は「患者間違い」, 「薬郕間 違い」, 「規格間違い」, 「重複投与」, 「投与量間違 い」,「中止すべき薬の投与」,「投与すべき薬の中 止 (投与忘れ) 」,「投与日時・時間の間違い」,「医 療機器に関するトラブル（機械の故障, ルート上 漏れ，ルート設定間違いなどのトラブル)」，「投 与速度間違い（投与速度設定間違い, 投与速度未 変更)」「「その他」とし, 1 事例につき 1 つヒヤリ・ ハット内容を選択した。

当事者経験年数は事例内に収録されている経験 年数を 1 年未満と 1 年以上に分類した.

原因薬は事例内の関連医薬品に記載されず事例 概要内に記載されていることも多いため, 関連医 薬品, 事例概要内から抽出した. 抽出した原因薬 のうち商品名で書かれているものは“JAPIC 医療 用 - 一般用医薬品集” (一般財団法人日本医薬情 報センター2015 年 7 月, 東京）を用いて一般名 へ変更した. な打抗生剤の溶媒として使用されて いる生理食塩液・ブドウ糖液は除外した。また, 原因薬による要因を明らかにするため, 原因薬群 に分類した．原因薬群はハイリスク薬である抗悪 性腫瘍剂，免疫抑制剂（ステロイドとそれ以外の 免疫抑制剂), 不整脈用剂, 抗てんかん剂, 血液 凝固阻止剂（抗凝固薬と抗血小板薬），ジギタリ ス製剤, テオフィリン製剤, カリウム製剤, 精神 神経用剂, 糖尿病用剂, 膵臓ホルモン剂, 抗ヒト 
免疫不全ウイルス（human immunodeficiency virus: HIV）薬と麻薬, 利尿剤, 感染症治療薬に分類し た。なお，カリウム製剤の郕形は注射薬，ステロ イドの鼡形は注射薬と内服薬とした。

発生要因は事例内に収録され分類されている 「確認を意った」，「患者への説明が不十分であっ た（总った）」「判断を誤った」，「観察を意った」， 「記録などに不備があった」，「連携ができていな かった」，「報告が遅れた（意った）」とした。

\section{3. 調查方法}

過剰投与群, 過小投与群のヒヤリ・ハット内容, 原因薬を集計した．原因薬は 1 事例で複数報告さ れていることもあるため, 累計件数で集計した. なお，重複して報告されている事例，内容が過剰 投与, 過小投与でない事例, 薬の自己管理など患 者側の責任で起きた事例, 当事者職種が看護師, 准看護師, 助産師以外の事例は除外した。

過剰投与群，過小投与群のヒヤリ・ハット内容 の上位 2 内容について，それぞれのヒヤリ・ハッ 卜内容 (ケース群) とそれ以外のヒヤリ・ハット 内容（コントロール群）の 2 群間でヒヤリ・ハッ 卜の背景因子（経験年数, 原因薬群, 発生要因) の比較を行った.

\section{4. 統計解析}

ケース群とコントロール群の 2 群間における背景 因子（経験年数, 原因薬群, 発生要因) について 単変量ロジスティック回帰分析を行った. さらに, 単変量ロジスティック回帰分析にて $P<0.2$ を認め たヒヤリ・ハットの背景因子を選択し， ステップワ イズ増加法による多変量ロジスティック回帰分析を
行った. 有意水準は $5 \%$ とし, 統計解析には IBM SPSS Statistics 24 (日本 IBM(株), 東京) を使用した。

\section{結果}

\section{1. 調査結果の概要}

2009 年 1 月 1 日〜 2015 年 6 月 30 日の過剩投与群 のヒヤリ・ハット事例は 3,024 件であった. このな かから重複して報告されている事例 33 件, 内容が 過剰投与でない事例 189 件, 薬の内服自己管理など 患者側の責任で起きた事例 713 件, 当事者職種が 看護師, 准看護師, 助産師以外の事例 114 件を除 いた対象事例は 1,975 件であった. 過小投与群は 2,119 件であった。このなかから重複して報告され ている事例 20 件, 内容が過小投与でない事例 118 件, 薬の自己管理など患者側の責任で起きた事例 325 件, 当事者職種が看護師, 准看護師, 助産師以外 の事例 59 件を除いた対象事例は 1,597 件であった。

\section{2.ヒヤリ・ハット内容}

過剒投与群，過小投与群のヒヤリ・ハット内容 を表 1 に示す。過剰投与群では投与量間違いが 785 件と最も多く, 次いで中止すべき薬の投与が 482 件であった. 過小投与群では投与量間違いが 902 件と最も多く, 次いで継続すべき薬の中止が 366 件であった。

\section{3. 原因薬}

過㮃投与群, 過小投与群の上位 10 原因薬を表 2 に示す。過剩投与群ではインスリンヒト（遺伝 子組み換え）が 115 件と 1 番多く，フロセミドが 108 件, ワルファリンカリウムが 82 件と続いた.

表 1 過剩投与群・過小投与群のヒヤリ・ハット内容

\begin{tabular}{|c|c|c|c|}
\hline 過剩投与群 & $\mathrm{n}$ & 過小投与群 & $\mathrm{n}$ \\
\hline 投与量間違い & 785 & 投与量間違い & 902 \\
\hline 中止すべき薬の投与 & 482 & 継続すべき薬の中止 & 366 \\
\hline 投与速度間違い & 305 & 投与速度間違い & 155 \\
\hline 重複投与 & 172 & 医療機器に関するトラブル & 113 \\
\hline 投与日時, 時間の間違い & 152 & 規格間違い & 31 \\
\hline 規格間違い & 36 & 投与日時, 時間の間違い & 26 \\
\hline 薬剤間違い & 15 & その他 & 2 \\
\hline 患者間違い & 14 & 患者間違い & 1 \\
\hline 医療機器に関するトラブル & 9 & 薬剤間違い & 1 \\
\hline その他 & 5 & & \\
\hline
\end{tabular}


過小投与群ではオキシコドン塩酸塩水和物が 54 件と 1 番多く，ワルファリンカリウムが 49 件, フロセミドが 38 件と続いた.

\section{4. ヒヤリ・ハット内容の上位におけるヒヤリ・ ハット背景 \\ （1）過剰投与群の投与量間違い}

投与量間違いのヒヤリ・ハットの背景の単変量 ロジスティック回帰分析の結果を表 3 に示す。経
験年数では有意な関連が認められなかった，有意 な正の関連が認められた原因薬は, 感染症治療薬, 抗凝固薬, 麻薬, ステロイド, 精神神経用剂, 抗 てんかん剤であり，発生要因は，「確認を意った」 であった。また，投与量間違いのヒヤリ・ハット の背景の多変量ロジスティック回帰分析の結果を 表 4 に示す. 有意な正の関連が認められた原因 薬（オッズ比, $95 \% \mathrm{Cl}$ ) は, 感染症治療薬（2.5, 1.8-3.6), 抗凝固薬 $(1.9,1.3-2.7)$, 麻薬（5.5,

表 2 過剩投与群 ・ 過小投与群の上位 10 原因薬

\begin{tabular}{lclc}
\hline \hline \multicolumn{1}{c}{ 過剩投与群 } & $\mathrm{n}$ & \multicolumn{1}{c}{ 過小投与群 } & $\mathrm{n}$ \\
\hline インスリンヒト（遺伝子組換え） & 115 & オキシコドン塩酸塩水和物 & 54 \\
フロセミド & 108 & ワルファリンカリウム & 49 \\
ワルファリンカリウム & 82 & フロセミド & 38 \\
維持液 & 51 & インスリンヒト（遺伝子組換え） & 36 \\
オキシゴン塩酸塩水和物 & 41 & ヘパリンナトリウム & 32 \\
ペリンナトリウム & 39 & プレドニゾロン & 27 \\
アスピリン & 29 & ドパミン塩酸塩 & 23 \\
バンコマイシン塩酸塩 & 26 & 維持液 & 21 \\
プレドニゾロン & 23 & インスリンアスパルト（遺伝子組換え） & 21 \\
アムロジピンベシル酸塩 & 22 & モルヒネ塩酸塩水和物 & 19 \\
& & 大建中湯 & 19 \\
\hline
\end{tabular}

表 3 過剰投与群の投与量間違いにおけるヒヤリ・ハットの背景の単変量ロジスティック回帰分析

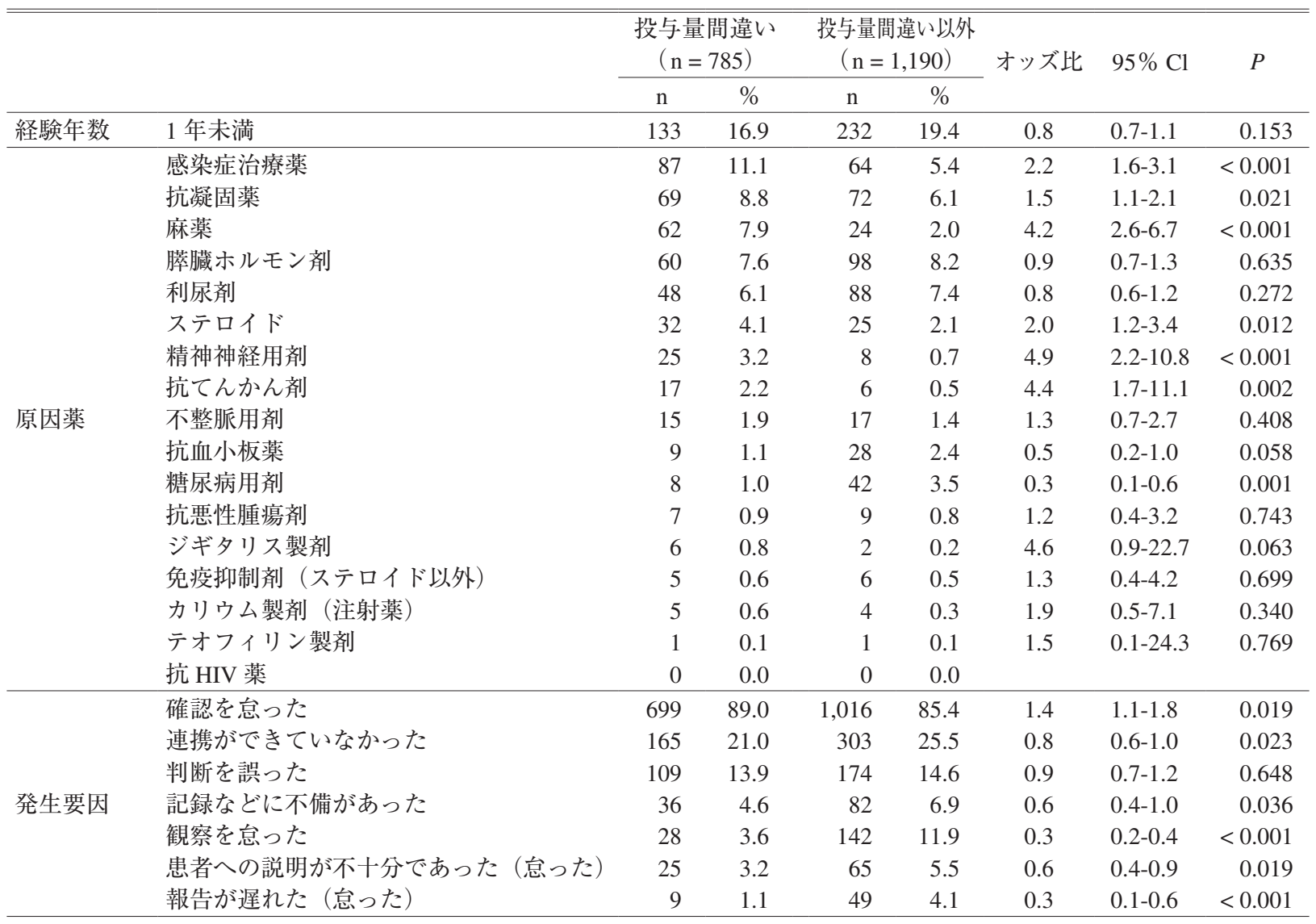

HIV: human immunodeficiency virus 
3.3-9.0), ステロイド $(2.3,1.3-3.9)$, 精神神経用 剂（6.1，2.7-13.9），抗てんかん剂（4.9, 1.9-12.4）, ジギタリス製剤（7.8，1.3-46.2），であり，発生 要因は,「確認を意った」（1.4, 1.0-1.8）であった. （2）過剰投与群の中止すべき薬の投与

中止すべき薬の投与のヒヤリ・ハットの背景の単
変量ロジスティック回帰分析の結果を表 5 に示す. 経験年数では有意な関連が認められなかった．有意 な正の関連が認められた原因薬は, 膵臓ホルモン郕, 利尿剂, 糖尿病用剂, 抗血小板薬であり, 発生要因 は，「連携ができていなかった」，「記録などに不備 があった」「患者への説明が不十分であった（意っ

表 4 過剩投与群の投与量間違いにおけるヒヤリ・ハットの背景の多変量ロジスティック回帰分析

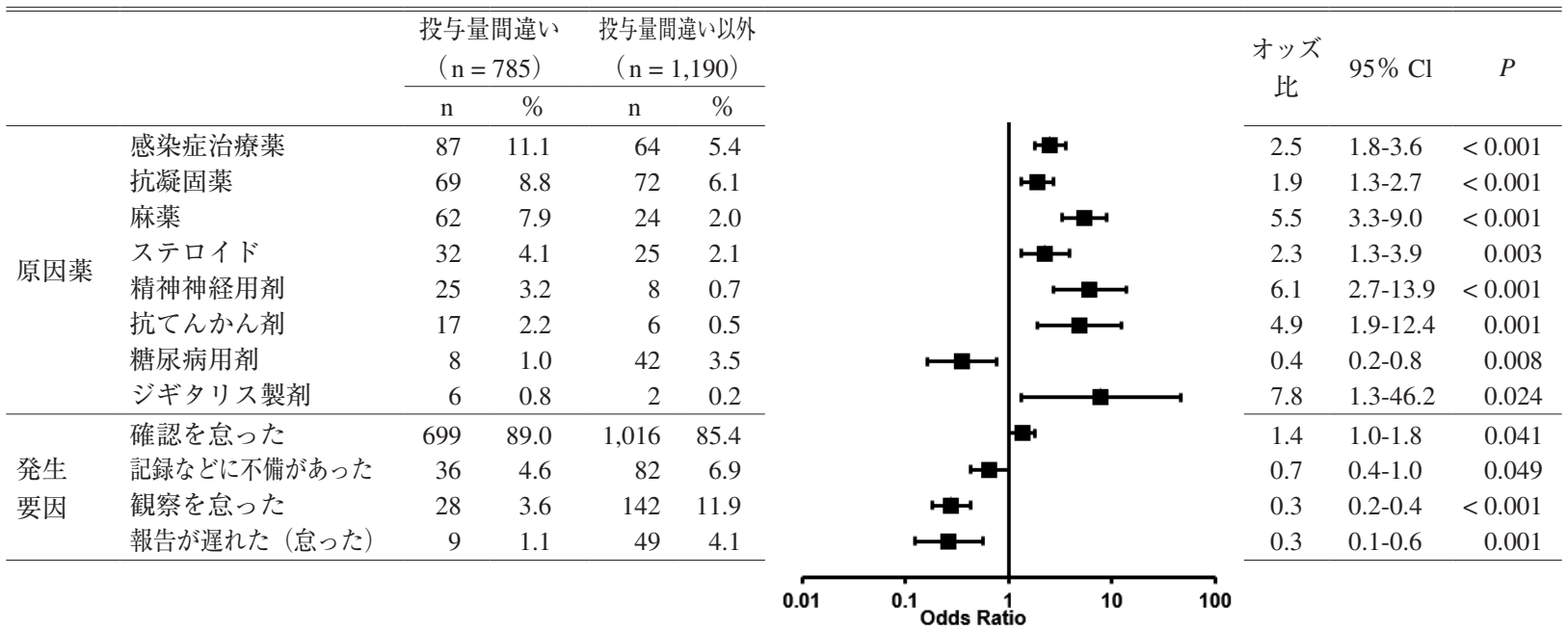

表 5 過剩投与群の中止すべき薬の投与におけるヒヤリ・ハットの背景の単変量ロジスティック回帰分析

\begin{tabular}{|c|c|c|c|c|c|c|c|c|}
\hline & & $\begin{array}{c}\text { 中止 } \\
\text { 薬 } 0 \\
(\mathrm{n}=\end{array}$ & & $\begin{array}{c}\text { 中止 } \\
\text { 薬の } \\
(\mathrm{n}=\end{array}$ & $\begin{array}{l}\text { ベき } \\
\text { †以外 } \\
\text { 493） }\end{array}$ & オッズ比 & $95 \% \mathrm{Cl}$ & $P$ \\
\hline & & $\mathrm{n}$ & $\%$ & $\mathrm{n}$ & $\%$ & & & \\
\hline 経験年数 & 1 年未満 & 91 & 18.9 & 274 & 18.4 & 1.0 & $0.8-1.3$ & 0.795 \\
\hline & 膵臟ホルモン剂 & 63 & 13.1 & 95 & 6.4 & 2.2 & $1.6-3.1$ & $<0.001$ \\
\hline & 利尿剂 & 49 & 10.2 & 87 & 5.8 & 1.8 & $1.3-2.6$ & 0.001 \\
\hline & 抗凝固薬 & 34 & 7.1 & 107 & 7.2 & 1.0 & $0.7-1.5$ & 0.933 \\
\hline & 感染症治療薬 & 31 & 6.4 & 120 & 8.0 & 0.8 & $0.5-1.2$ & 0.250 \\
\hline & 糖尿病用剂 & 24 & 5.0 & 26 & 1.7 & 3.0 & $1.7-5.2$ & $<0.001$ \\
\hline & 抗血小板薬 & 17 & 3.5 & 20 & 1.3 & 2.7 & $1.4-5.2$ & 0.003 \\
\hline & 不整脈用剂 & 8 & 1.7 & 24 & 1.6 & 1.0 & $0.5-2.3$ & 0.937 \\
\hline & ステロイド & 7 & 1.5 & 50 & 3.3 & 0.4 & $0.2-0.9$ & 0.036 \\
\hline 原因薬 & 麻薬 & 6 & 1.2 & 80 & 5.4 & 0.2 & $0.1-0.5$ & $<0.001$ \\
\hline & 精神神経用剂 & 5 & 1.0 & 28 & 1.9 & 0.5 & $0.2-1.4$ & 0.219 \\
\hline & 抗てんかん剂 & 4 & 0.8 & 19 & 1.3 & 0.6 & $0.2-1.9$ & 0.434 \\
\hline & 抗悪性腫瘍剤 & 4 & 0.8 & 12 & 0.8 & 1.0 & $0.3-3.2$ & 0.956 \\
\hline & 免疫抑制剂（ステロイド以外） & 1 & 0.2 & 10 & 0.7 & 0.3 & $0.0-2.4$ & 0.263 \\
\hline & カリウム製剤（注射薬） & 1 & 0.2 & 8 & 0.5 & 0.4 & $0.1-3.1$ & 0.370 \\
\hline & ジギタリス製荗 & 1 & 0.2 & 7 & 0.5 & 0.4 & $0.1-3.6$ & 0.445 \\
\hline & テオフィリン製剤 & 0 & 0 & 2 & 0.1 & & & \\
\hline & 抗 HIV 薬 & 0 & 0 & 0 & 0 & & & \\
\hline & 確認を意った & 394 & 81.7 & 1321 & 88.5 & 0.6 & $0.4-0.8$ & $<0.001$ \\
\hline & 連携ができていなかった & 138 & 28.6 & 330 & 22.1 & 1.4 & $1.1-1.8$ & 0.003 \\
\hline & 判断を誤った & 73 & 15.1 & 210 & 14.1 & 1.1 & $0.8-1.5$ & 0.557 \\
\hline 発生要因 & 記録などに不備があった & 42 & 8.7 & 76 & 5.1 & 1.8 & $1.2-2.6$ & 0.004 \\
\hline & 患者への説明が不十分であった（意った） & 39 & 8.1 & 51 & 3.4 & 2.5 & $1.6-3.8$ & $<0.001$ \\
\hline & 報告が遅れた（总った） & 24 & 5.0 & 34 & 2.3 & 2.2 & $1.3-3.8$ & 0.003 \\
\hline & 観察を意った & 22 & 4.6 & 148 & 9.9 & 0.4 & $0.3-0.7$ & $<0.001$ \\
\hline
\end{tabular}

HIV: human immunodeficiency virus 
た）」「「報告が遅れた（忠った）」であったままた， 中止すべき薬の投与のヒヤリ・ハットの背景の多変 量ロジスティック回帰分析の結果を表 6 に示す．有 意な正の関連が認められた原因薬は, 膵臟ホルモン 凨 (2.5, 1.8-3.5), 利尿剂 $(2.0,1.4-2.9)$, 糖尿病用 凨（3.1, 1.8-5.6), 抗血小板薬（2.6, 1.3-5.2）であり, 発生要因は,「連携ができていなかった」(1.3,1.0-1.7),
「記録などに不備があった」（1.6，1.0-2.4），「患者へ の説明が不十分であった (急った)」(2.0,1.2-3.1),「報 告が遅れた（意った）」（2.2，1.3-4.0）であった.

\section{（3）過小投与群の投与量間違い}

投与量間違いのヒヤリ・ハットの背景の単変量 ロジスティック回帰分析の結果を表 7 に示す。経 験年数では有意な負の関連が認められた．有意な

表 6 過剰投与群の中止すべき薬の投与におけるヒヤリ・ハットの背景の多変量ロジスティック回帰分析

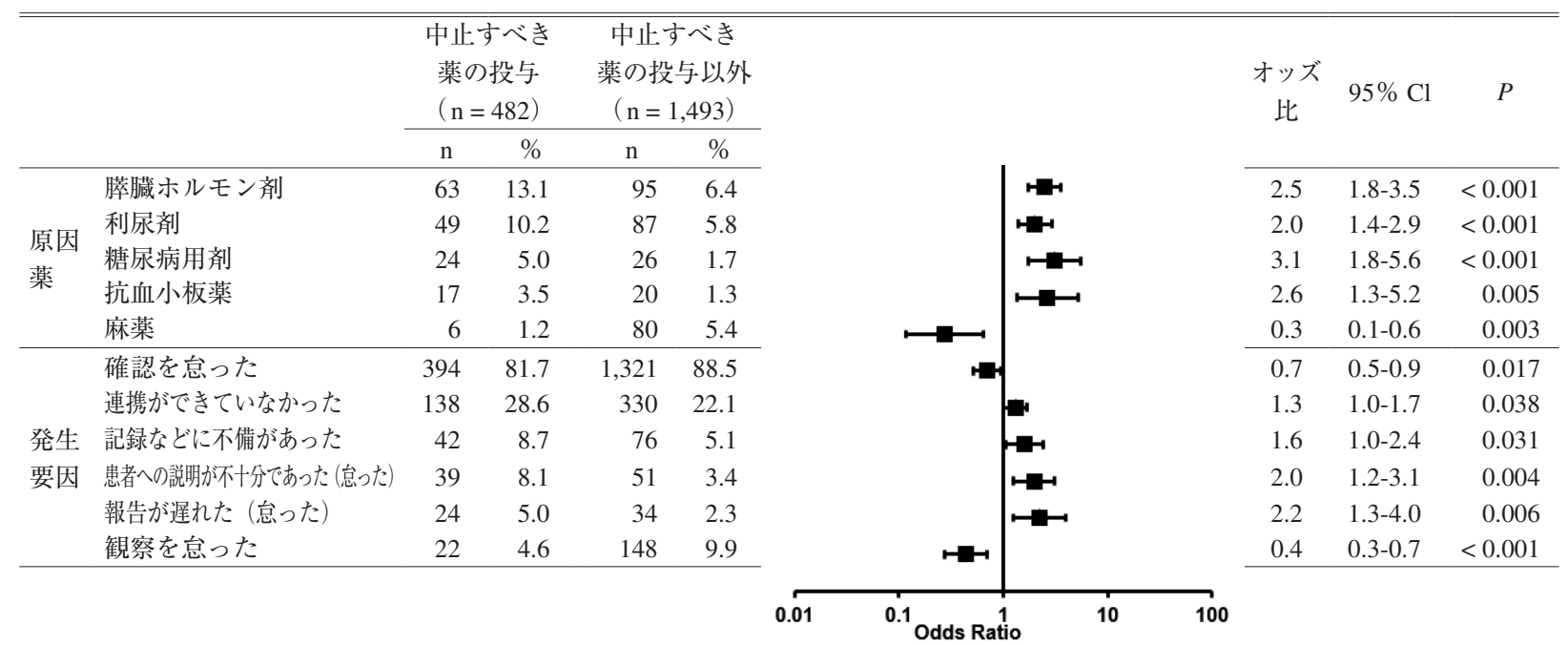

表 7 過小投与群の投与量間違いにおけるヒヤリ・ハットの背景の単変量ロジスティック回帰分析

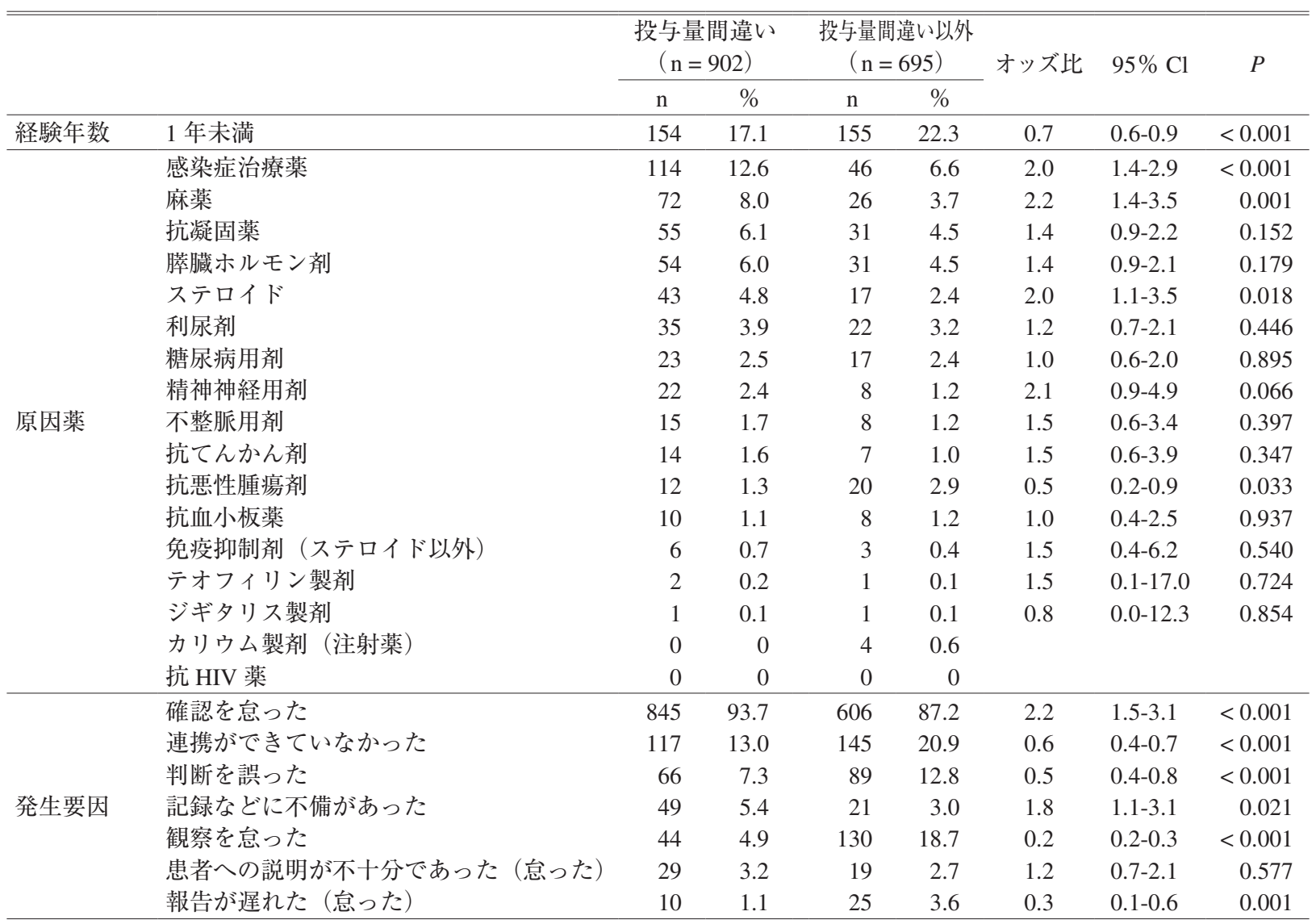

HIV: human immunodeficiency virus 
正の関連が認められた原因薬は, 感染症治療薬, 麻薬, ステロイドであり, 発生要因は,「確認を吝っ た」,「記録などに不備があった」であった。 また， 投与量間違いのヒヤリ・ハットの背景の多変量口 ジスティック回帰分析の結果を表 8 に示す。経 験年数では有意な負の関連が認められた，有意な 正の関連が認められた原因薬は，感染症治療薬 (2.2, 1.5-3.2), 麻薬 (2.8, 1.7-4.6), 抗凝固薬（1.6,
1.0-2.7)，ステロイド $(2.0,1.1-3.7 ）$ であり，発 生要因は,「確認を意った」（1.9, 1.3-2.7), 「記 録などに不備があった」（2.3，1.3-4.0）であった。

（4）過小投与群の継続すべき薬の中止

継続すべき薬の中止のヒヤリ・ハットの背景の 単変量ロジスティック回帰分析の結果を表 9 に 示す。経験年数では有意な関連が認められなかっ た. 有意な正の関連が認められた原因薬は抗悪性

表 8 過小投与群の投与量間違いにおけるヒヤリ・ハットの背景の多変量ロジスティック回帰分析

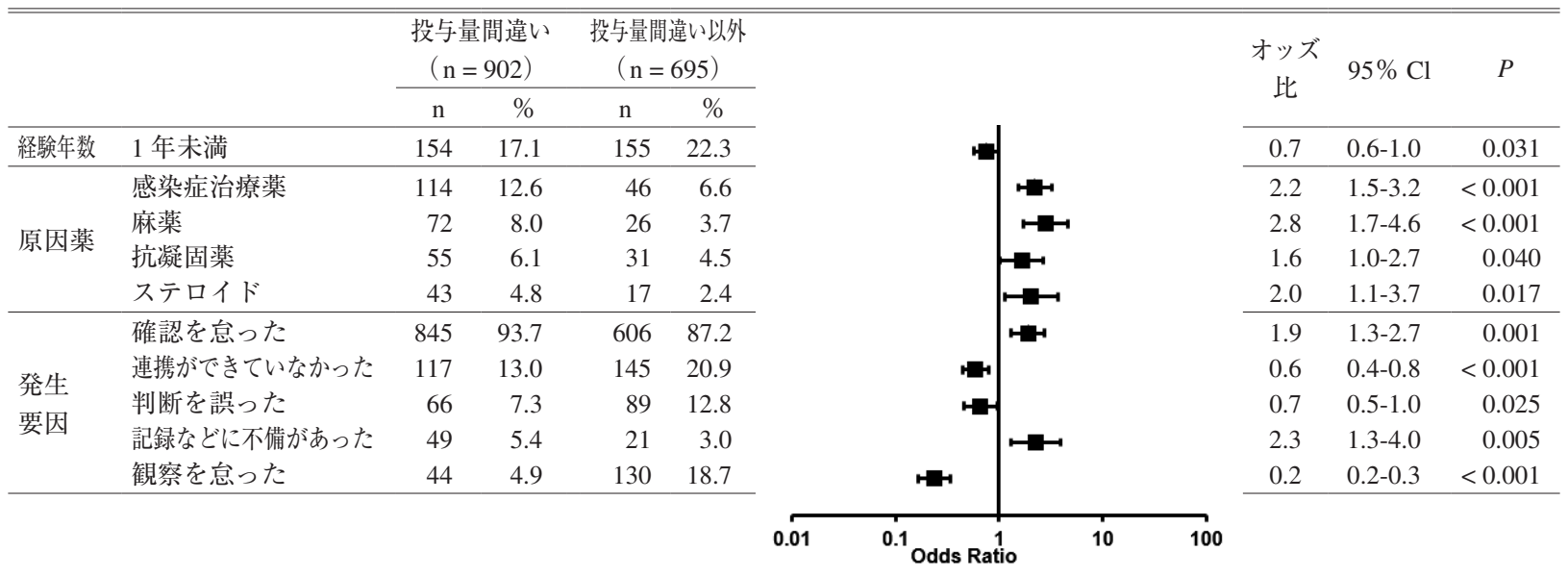

表 9 過小投与群の継続すべき薬の中止におけるヒヤリ・ハットの背景の単変量ロジスティック回帰分析

\begin{tabular}{|c|c|c|c|c|c|c|c|c|}
\hline & & \multicolumn{2}{|c|}{$\begin{array}{c}\text { 継続すべき } \\
\text { 薬の中止 } \\
(\mathrm{n}=366)\end{array}$} & \multicolumn{2}{|c|}{$\begin{array}{c}\text { 継続すべき薬 } \\
\text { の中止以外 } \\
(\mathrm{n}=1,231)\end{array}$} & \multirow[t]{2}{*}{ オッズ比 } & \multirow[t]{2}{*}{$95 \% \mathrm{Cl}$} & \multirow[t]{2}{*}{$P$} \\
\hline & & $\mathrm{n}$ & $\%$ & $\mathrm{n}$ & $\%$ & & & \\
\hline 経験年数 & 1 年未満 & 78 & 21.3 & 288 & 23.4 & 1.2 & $0.9-1.6$ & 0.279 \\
\hline \multirow{17}{*}{ 原因薬 } & 感染症治療薬 & 25 & 6.8 & 135 & 11.0 & 0.6 & $0.4-0.9$ & 0.022 \\
\hline & 膵臓ホルモン剂 & 20 & 5.5 & 65 & 5.3 & 1.0 & $0.6-1.7$ & 0.890 \\
\hline & 利尿剂 & 15 & 4.1 & 42 & 3.4 & 1.2 & $0.7-2.2$ & 0.535 \\
\hline & 抗凝固薬 & 14 & 3.8 & 72 & 5.8 & 0.6 & $0.4-1.1$ & 0.135 \\
\hline & 糖尿病用剂 & 14 & 3.8 & 26 & 2.1 & 1.8 & $1.0-3.6$ & 0.070 \\
\hline & 抗悪性腫瘍剂 & 13 & 3.6 & 19 & 1.5 & 2.3 & $1.1-4.8$ & 0.019 \\
\hline & ステロイド & 11 & 3.0 & 49 & 4.0 & 0.7 & $0.4-1.5$ & 0.391 \\
\hline & 麻薬 ～～～ & 9 & 2.5 & 89 & 7.2 & 0.3 & $0.2-0.6$ & 0.001 \\
\hline & 抗血小板薬 & 8 & 2.2 & 10 & 0.8 & 2.7 & $1.1-7.0$ & 0.036 \\
\hline & 精神神経用剂 & 6 & 1.6 & 24 & 1.9 & 0.8 & $0.3-2.1$ & 0.701 \\
\hline & 抗てんかん剂 & 6 & 1.6 & 15 & 1.2 & 1.4 & $0.5-3.5$ & 0.536 \\
\hline & 不整脈用剂 & 2 & 0.5 & 21 & 1.7 & 0.3 & $0.1-1.4$ & 0.121 \\
\hline & 免疫抑制剂（ステロイド以外） & 1 & 0.3 & 8 & 0.6 & 0.4 & $0.1-3.4$ & 0.413 \\
\hline & カリウム製剂（注射薬） & 1 & 0.3 & 3 & 0.2 & 1.1 & $0.1-10.8$ & 0.921 \\
\hline & テオフィリン製剂 & 1 & 0.3 & 2 & 0.2 & 1.7 & $0.2-18.6$ & 0.671 \\
\hline & ジギタリス製剤 & 1 & 0.3 & 1 & 0.1 & 3.4 & $0.2-54.0$ & 0.391 \\
\hline & 抗 HIV 薬 & 0 & 0 & 0 & 0 & & & \\
\hline \multirow{7}{*}{ 発生要因 } & 確認を怠った & 322 & 88.0 & 1,129 & 91.7 & 0.7 & $0.5-1.0$ & 0.030 \\
\hline & 連携ができていなかった & 82 & 22.4 & 180 & 14.6 & 1.7 & $1.3-2.3$ & $<0.001$ \\
\hline & 観察を意った & 39 & 10.7 & 135 & 11.0 & 1.0 & $0.7-1.4$ & 0.867 \\
\hline & 判断を誤った & 39 & 10.7 & 116 & 9.4 & 1.1 & $0.8-1.7$ & 0.485 \\
\hline & 患者への説明が不十分であった（忠った） & 16 & 4.4 & 32 & 2.6 & 1.7 & $0.9-3.2$ & 0.085 \\
\hline & 記録などに不備があった & 15 & 4.1 & 55 & 4.5 & 0.9 & $0.5-1.6$ & 0.762 \\
\hline & 報告が遅れた（怠った） & 10 & 2.7 & 25 & 2.0 & 1.4 & $0.6-2.8$ & 0.423 \\
\hline
\end{tabular}

HIV: human immunodeficiency virus 
表 10 過小投与群の継続すべき薬の中止におけるヒヤリ・ハットの背景の多変量ロジスティック回帰分析

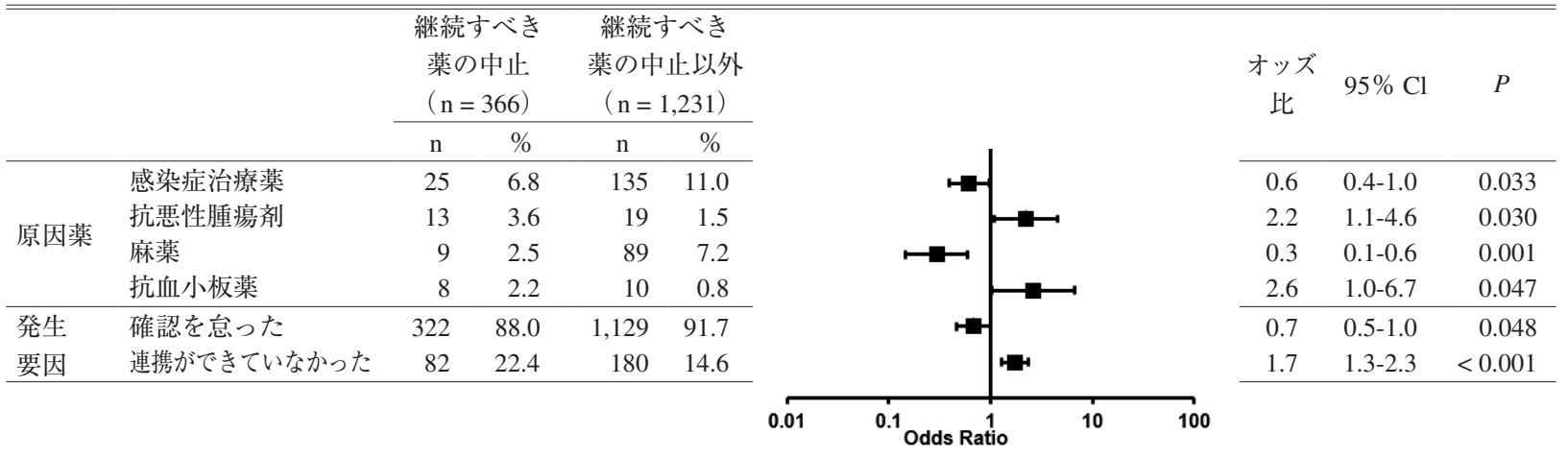

腫瘍剂，抗血小板薬であり，発生要因は，「連携 ができていなかった」であった。また，継続すべ き薬の中止の背景の多変量ロジスティック回帰分 析の結果を表 10 に示す，有意な正の関連が認め られた原因薬は，抗悪性腫瘍剂（2.2, 1.1-4.6）, 抗血小板薬（2.6, 1.0-6.7）であり, 発生要因は,「連 携ができていなかった」（1.7，1.3-2.3）であった。

\section{考察}

今回の調査から過㮃投与群，過小投与群のヒヤ リ・ハット内容や原因薬，発生要因が明らかに なった。

ヒヤリ・ハット内容では，過剩投与群，過小投 与群ともに投与量間違いが最も多かった．多変量 ロジスティック回帰分析の結果, 投与量間違いの 原因薬群では過剩投与群, 過小投与群ともに感染 症治療薬，麻薬，ステロイド，抗凝固薬，過㮃投 与群では精神神経用剂，抗てんかん剂，ジギタリ ス製剤で有意な関連が認められた。これらの薬で は患者の年歯令や腎臓の代謝能力, 状態, 検査值な どにより投与量が変わりやすいため投与量間違い が起こりやすいと考えられる。また, 1 回量が 2 錠や 3 錠など幅があり，与薬準備時，配薬時に投 与量間違いが起きる原因になると考えられる。過 剰投与群の原因薬群では膵臓ホルモン剂に有意な 正の関連はみられなかった。このことは膵蔵ホル モン剤であるインスリンの投与量間違いは低血糖 につながることを認識し，投与量に注意を払われ ていたことが要因の 1 つとして考えられる。発生 要因では「確認を意った」に有意な正の関連が認 められた。 与薬業務のどの段階で確認を意りやす
いかを調査した報告では，看護師が正しく指示を 受けた後, その指示に従ってこれから実施する行 動の手順（方法）を計画する段階で最も発生しや

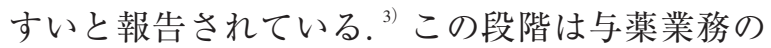
中で 1 回量ごとの薬の取り揃え段階にあたる。そ のため, 処方内容や投与量の把握をしやすい病棟 担当薬剤師が与薬前に投与量確認を行うことでヒ ヤリ・ハット減少に貢献できると考える。また, 薬袋のデザインを変更することで, 看護師が用 法・用量などの確認をしやすくし，ヒヤリ・ハッ 卜減少につなげた報告もあり, ${ }^{4,5)}$ 各施設において 薬袋が投与量間違いなどのヒヤリ・ハットに関与 している場合は, より投与量を確認しやすい薬袋 への変更を検討する必要がある.

過㮃投与群のヒヤリ・ハット内容では投与量間 違いに次いで，中止すべき薬の投与が多かった。 原因薬群では膵臓ホルモン剂, 糖尿病用剂, 利尿 剂，抗血小板薬で有意な正の関連が認められた。 これらの薬では, 患者の状態や食事摂取量, 検査 值，手術などの状況により中止になる可能性があ るため, 中止すべき薬の投与が起きやすいと考え られる。そのため, 病棟などで行われるカンファ レンスや回診に参加して手術予定などの情報共有 し, 抗血小板薬などの休薬状況や休薬期間の確認 を徹底していくことが必要である。また，インス リンなどの膵臓ホルモン剂, 糖尿病用剂など食事 状況や血糖值に合わせて, その都度薬の中止の判 断が必要な薬を使用している患者には与薬時に看 護師に同行して, その時の状態に合わせた薬の中 止の判断, 確認を行うことも検討する必要がある. 発生要因では「連携ができていなかった」,「記録 などに不備があった」,「患者への説明が不十分で 
あった（总った）」や「報告が遅れた（意った）」 で有意な関連が認められた. 看護師は業務上,ナー スコールや患者の急変などにより作業中断があ り，1つの業務に集中して取り組むことが困難な 背景がある. ${ }^{6}$ これらの業務状況がヒヤリ・ハッ 卜発生の要因の 1 つにあると考えられる. 従って, 薬の中止などの処方変更があった際には医師や看 護師が薬剤師に連絡し, 薬殽師が中止薬の抜取り 作業や患者への説明を行うなど役割分担をしてい くことでヒヤリ・ハット減少に貢献できると考え る.

過小投与群のヒヤリ・ハット内容で投与量間違 いに次いで，継続すべき薬の中止（投与忘れ）が 多かった，継続すべき薬の中止について原因薬で は, 抗悪性腫痬剂, 抗血小板薬で有意な正の関連 が認められた．抗悪性腫瘍剂は投与スケジュール が各薬剤で異なり, 症状や検査值, 副作用の程度 により休薬, 再開が行われる. 抗血小板薬も手術 後の全身状態, 出血等確認して再開される. その ため，継続すべき薬の中止（投与忘れ）の原因薬 になったと考えられる。発生要因では「連携がで きていなかった」で有意な正の関連が認められた。 そのため, 薬剤師が医師や看護師と連携し, 情報 共有を行い，投薬状況を把握することで継続すべ き薬の中止（投与忘れ）の減少に貢献できると考 える.

今回の調査では経験年数が 1 年未満の新人看護 師と過剩投与群の投与量間違いや中止すべき薬の 投与, 過小投与群の投与量間違いや継続すべき薬 の中止において有意な正の関連を認めなかった. このことより，新人看護師は特定のヒヤリ・ハッ 卜内容のみをおこすわけでないため，与薬の場面 では薬剤の投与量や薬剤の継続, 中止などの指示, 処方の有無などの確認が必要である．なお，過剩 投与群, 過小投与群のヒヤリ・ハット内容上位 2 内容において当事者の $80 \%$ 前後は経験年数が 1 年以上の看護師であり, 薬剤師は看護師の経験年 数にかかわらず，ヒヤリ・ハットを未然に防止す るよう関与していく必要がある。

研究の限界として, 今回使用したデータベース は自発的かつ任意に報告されているため, 報告バ イアスは排除できない。 また，麻薬のように医薬
品管理上重要な薬は, 漏れがなく報告されたため, 報告件数が多かったと考えられる。また，自発報 告の場合は，発現割合を算出する分母が存在しな い.?そのため, 今回の結果から得られたオッズ 比は, ヒヤリ・ハット内容との因果関係の強さを 示すものではないため, 結果の解釈に十分注意を 払う必要がある。しかしながら, データベースに 収載されている事例情報は, 医療安全対策に有用 な情報を共有し, 同様なヒヤリ・ハット発生予防, 再発防止の推進に取り組む全国 643 施設からの報 告（http://www.med-safe.jp/pdf/business_pamphlet_ 2016_01.pdf, 2017 年 11 月 1 日）である.このこ とを考慮すると, 日本全国のヒヤリ・ハットの発 生状況が反映されていると考えられ, 今回の結果 は多くの医療機関で活用できると考えられる.

医療現場に打ける安全管理は複雑, かつ多様化 してきている，病棟での薬剤関連の業務の多くは 看護師や医師によって行われており，ヒヤリ・ ハットの当事者の職種は看護職が最も多く, 次い で医師である（http://www.med-safe.jp/pdf/year_ report_2015.pdf, 2017 年 11 月 1 日)。また看護師 の与薬では未然にエラーが発見されにくい ${ }^{8}$ こと からも，薬の専門家である薬剤師が介入していく ことが必要である. 今回の調査から, 過剩投与, 過小投与のヒヤリ・ハット内容や原因薬, 発生要 因が明らかになり薬剤師が介入すべき点を示すこ とができた，以上を踏まえ，薬剤師は調剂や服薬 指導だけでなく患者が薬を服用するまでの安全管 理に積極的にかかわることでより安全で確実な医 療に貢献できると考える.

\section{利益相反}

開示すべき利益相反はない.

\section{引用文献}

1）河西洋子, 石川陽子, 習田明裕, 志自岐康子, 交代 制勤務を行う看護師のヒヤリ・ハット,インシ デント,アクシデントに関連する要因, 日本保健 科学学会誌, 2016, 19, 14-23.

2）竹内仁司, 金崎洋子, 山本浩和, 牧野泰裕, 斎藤 大治, 小長英二, インシデント報告からみた誤薬 
予防対策, 医療, 2003, 57, 558-561.

3）濱田康代, 田口大介, 酒井美絵子, 村田加奈子, 川村佐和子, 看護師の内服与薬業務における「確 認エラー」に関する検討, 日本看護管理学会誌, 2006, 9 (2), 31-40.

4) 安永大輝, 田中亮裕, 松岡 綾, 田中守, 池川 嘉郎, 末丸克矢, 荒木博陽, 内服薬に関するイン シデントの要因分析と薬袋の関与, 日本病院薬 片師会雑誌, 2013, 49, 743-746.

5）渡邊真一, 桑原由衣, 安永大輝, 飛鷹範明, 加戸 佳己, 岡本千恵, 田中 守, 田中亮裕, 荒木博陽, 持参薬薬袋作成による医療安全上の貢献と業務 負担軽減に関する取り組み, 日本病院薬荗師会 雑誌, 2015, 51, 1005-1008.

6）八代利香, 松成裕子, 梯 正之, 看護職における $\lceil$ 与薬エラー発生」に関わる要因 : 国内外の研 究動向と今後の課題, 日本職業・災害医学会会 誌, 2004, 52, 299-307.

7）高橋行雄, 日本の公開医薬品副作用データベー スの活用, 薬剂疫学, 2014, 19, 14-22.

8) Leape LL, Bates DW, Cullen DJ, Cooper J, Demonaco HJ, Gallivan T, Hallisey R, Ives J, Laird N, Laffel G, Nemeskal R, Petersen LA, Porter K, Servi D, Shea BF, Small SD, Sweitzer BJ, Thompson BT, Vliet MV, Bates D, Hojnowski-Diaz P, Petrycki S, Cotugno M, Patterson H, Hickey M, Kleefield S, Kinneally E, Clapp MD, Hackman JR, Edmondson A, ADE Prevention Study Group, Systems analysis of adverse drug events, JAMA, 1995, 274, 35-43. 